\title{
PERWUJUDAN NILAI MORALITAS DALAM MENGAWAL PEMILIHAN PRESIDEN 2019 YANG DEMOKRATIS DAN BERKEADILAN
}

\author{
Dimas Bima Setiyawan \\ Program Magister Universitas Islam Negeri (UIN) Sunan Kalijaga \\ Yogyakarta \\ Jl. Laksda Adisucipto, Papringan, Caturtunggal, Kec. Depok, Kabupaten Sleman, \\ Daerah Istimewa Yogyakarta 55281, Indonesia| Bimasaktid1410@gmail.com \\ DOI: https://doi.org/10.35719/ijl.v1i2.94
}

\begin{abstract}
Moral is an ethic inherent ain a human being. Formed trough verous diverse events that have been passed, one of wich is trough the role of religion. The importance of the role is broken down in the form of behavior of each individual in response to everything that is present in his life. Religion was reveald for justice, morality, mutual respect, and called for creating a peaceful order of live among fellow human beings. The importance of promoting morality based on religion will greatly affect the pattern of life carried out by every human being. one of them is responding to the upcoming 2019 preidential election. The values contained in it will certainly influence the realization of the five-year event to realize a democratic and justice election system.

Keywords : Morality, Religion, Presiden Election, Democracy And Justice
\end{abstract}

Abstrak : Moral merupakan etika yang melekat pada diri seorang manusia. Terbentuk melalui berbagai kejadian beragam yang telah terlewati, salah satunya adalah melalui peranan Agama. Pentingnya peranan itu terurai dalam bentuk tingkah laku dari setiap individu tadi dalam merespon segala sesuatu yang hadir dalam kehidupannya. Agama diturunkan untuk keadilan, berkeadaban, saling menghormati dan menghargai, serta menyerukan untuk menciptakan tatanan kehidupan yang damai antar sesama manusia. Pentingnya menanmkan moralitas berpedoman pada agama akan sangat mempengaruhi pola kehidupan yang dilakukan oleh setiap manusia. Salah satunya adalah merespon Pemilihan Presiden 2019

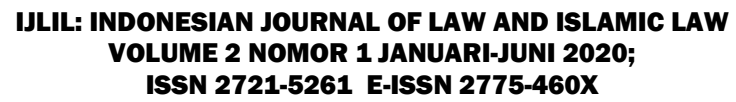


yang akan datang. Nilai-nilai yang terkandung didalamnya pasti akan mempengaruhi terwujudnya perhelatan lima tahunan tadi untuk mewujudkan sebuah tatanan pemilihan yang demokratis dan berkeadilan.

Kata Kunci : Moralitas, Agama, Pemilihan Presiden, Demokrasi.

\section{Pendahuluan}

Pemilu Presiden secara langsung pertama kali digelar pada tahun 2004. Sebelumnya, presiden dan wakil presiden dipilih anggota Majelis Permusyawaratan Rakyat dengan suara terbanyak. Pada sidang paripurna MPR pada 9 November 2001 melakukan amandemen dan mengganti sistem pemilihan presiden menjadi sistem pemilihan presiden secara langsung yakni oleh rakyat. Pasal 1 Ayat (2) UUD Negara Republik Indonesia Tahun 1945 (UUD NRI 1945) menyatakan bahwa kedaulatan berada ditangan rakyat dan dilaksanakan menurut undang-undang. Begitu pula Pasal 6A Ayat (1) UUD NRI 1945 presiden dan wakil presiden dipilih secara langsung oleh rakyat. ${ }^{1}$ Selanjutnya, dalam Pasal 6A ayat (5) UUD NRI 1945 ditegaskan bahwa tata cara pelaksanaan pemilihan presiden dan wakil presiden lebih lanjut diatur dalam undang-undang.

Undang-Undang Nomor 23 Tahun $2003^{2}$ yang menjadi

\footnotetext{
"Umbu Rauta, "Menggagas Pemilihan Presiden Yang Demokratis Dan Aspiratif," Jurnal Konstitusi 11, no. 3 (2014): 601.

${ }^{2}$ Lembaran Negara Republik Indonesia Tahun (LNRI) 2003 Nomor 93, Tambahan LNRI Nomor 4311.
} 
landasan penyelenggaraan pilpres 2004. Saat pilpres 2009, Undang-Undang Nomor 23 Tahun 2003 dicabut dan diganti dengan Undang-Undang Nomor 42 Tahun 2008.3 Selain Undang-Undang Nomor 42 Tahun 2008, penyelenggaraan pilpres 2009 juga didasarkan pada Undang-Undang Nomor 22 Tahun 2007 tentang Penyelenggara Pemilihan Umum. ${ }^{4}$ Pada pilpres 2014 ini, masih menggunakan Undang-Undang Nomor 42 Tahun 2008, meski pada awal 2013 DPR mengagendakan perubahan, namun sebagian besar fraksi menolak untuk dilakukan perubahan. ${ }^{5}$

Pada perhelatan Pemilu tahun 2019 Rancangan Undangundang Pemilu telah ditetapkan dalam sidang paripurna DPR dan kini sudah diresmikan oleh Presiden Joko Widodo pada tanggal 15 Agustus $2017^{6}$, yakni lahirnya Undang-undang Nomor 7 Tahun 2017 tentang Pemilihan Umum $^{7}$ dan menjadi dasar hukum penyelenggaraan Pemilu DPR, DPD, DPRD dan Pemilihan Presiden pada tahun 2019 yang dislenggarakan secara serentak dilaksanakan secara langsung, umum, bebas, rahasia, jujur dan adil. ${ }^{8}$

\footnotetext{
3 LNRI Tahun 2008 Nomor 176, Tambahan LNRI Nomor 4924.

${ }^{4}$ LNRI Tahun 2007 Nomor 59, Tambahan LNRI Nomor 4721.

5 Beberapa ketentuan dalam UU No. 42 Tahun 2008 telah diajukan pengujian ke Mahkamah Konstitusi dan dinyatakan bertentangan dengan UUD NRI 1945 sehingga tidak mempunyai kekuatan hukum mengikat, melalui Putusan MK No. 14/PUU/XI/2013, tanggal 23 Januari 2014

${ }^{6} \mathrm{http} / / /$ www.kpujepara.go.id/inilah-undang-undang-yang-menjadi-dasar-pemilu2019/, Di akses pada 14 September 2018.

7Tambahan Lembaran Negara Republik Indonesia Nomor 6109

${ }^{8}$ Pasal 22E Ayat (1) UUD 1945 : Pemilihan Umum dilaksanakan secara langsung, umum, bebas, rahasia, jujur dan adil setiap lima tahun sekali.
} 
Secara konseptual Ibnu Tricahyo, mendefinisikan pemilu merupakan instrumen untuk mewujudkan kedaulatan rakyat yang bermaksud membentuk pemerintahan yang absah serta sarana mengartikulasikan aspirasi dan kepentingan rakyat. ${ }^{9}$ Secara operasional Pratikno menyatakan bahwa pemilu merupakan mekanisme politik untuk mengkonversi suara rakyat (votes) menjadi wakil rakyat (seats). ${ }^{10}$ Pemilu merupakan suatu arena kompetisi dan menag kalah ditentukan oleh rakyat melalui pemungutan suara, oleh karena itu pemilu memberikan kesempatan bagi warga negara untuk memilih pejabat pemerintah yang benar-benar dianggap mampu untuk mengaspirasikan kehendak mereka.

Mengingat pemilihan umum presiden dan wakil presiden tahun 2014, masyarakat Indonesia terbelah menjadi dua bagian. Sekarang perpecahan itu sudah mulai terasa. Pertentangan politik mulai tertata untuk mensukseskan pemilihan presiden 2019. Pertama, sangat pro dengan kubu Prabowo-Sandi, demikian yang kedua, pro dengan JokowiMakruf Amin. Perpecahan ini terjadi secara langsung maupun tidak langsung. Secara langsung dengan mengumumkan dukungannya kepada salah satu calon kepada seluruh masyarakat sehingga sudah terpetakan yang mendukung dan

\footnotetext{
9 Ibnu Tricahyo, Reformasi Pemilu Menuju Pemisahan Pemilu Nasional dan Lokal, (Malang : In Trans Publishing, 2009), 6.

${ }^{10}$ Muhadam Labolo, Teguh Ilham., Partai Politik dan Sistem Pemilihan Umum DI Indonesia, (Jakarta, Rajawali Perss, 2015), 51.
} 
yang tidak mendukung.

Kejadian mengakibatkan retaknya kerukunan sosial akibat pemilu nyata adanya, seperti survei yang telah dilakukan lembaga survei PolMark Indonesia. lembaga riset Polmark Indonesia menyebut retaknya kerukunan sosial akibat pemilu nyata adanya. Kesimpulan itu didapat berdasarkan hasil survei yang sempat dilakukan dalam dua hari terakhir. Ada peningkatan potensi rusaknya kerukunan sosial selama 2014-2017. Potret peningkatan itu didapat dari hasil survei saat pilpres 2014 dan pilkada DKI Jakarta 2017. Berdasarkan survei pilpres 2014, ada 95,2 persen pemilih yang mengakui tidak rusak hubungan pertemanannya pasca pemilihan saat itu, sementara di survei 2017 ada 93,8 persen responden menyambut hal yang sama. ${ }^{11}$

Terbukti dengan tindakan yang telah dilakukan belakangan ini seperti yang dikutip dari Jakarta, IDN Times, kasus persekusi yang menimpa Susi Ferawati dan sang buah hati, Davin di kegiatan Car Free Day. Ia mendapatkan pelecehan secara verbal maupun non verbal dan memperkarakan kejadian tersebut kepada pihak yang berwajib. ${ }^{12}$ Kejadian serupa juga terjadi pada laman Facebook

"Lalu Rahadian, "Catatan PolMark: Perpecahan Masyarakat Karena Pemilu Nyata," tirto.id, n.d.https://tirto.id/catatan-polmark-perpecahan-masyarakat-karena-pemilunyata-cVHj Diakses pada 20 September 2018

${ }^{12}$ Jakarta, IDN Times- Kasus persekusi yang menimpa Susi Ferawati dan sang buah hati, Devin. Kejadian tersebut terjadi pada hari Minggu (29/4) silam di kegiatan Car Free Day. Massa yang menggunakan kaus \#2019gantipresiden. Susi mengaku mendapat pelecehan secara verbal maupun non verbal. Tidak terima ia melaporkan 
dan Instagram yang secara langsung dan terbuka menyatakan dukunganya kepada salah satu calon dan pada laman tersebut mereka bersihtegang mempertentangkan dukungannya melalui berbagai cara, seperti memanipulasi data, gambar dan lain sebagainya. ${ }^{3}$

Tindakan tersebut sangatlah disayangkan, mengapa mereka menggunakan tunggangan sedemikan rupa hanya untuk mengutarakan pilihannya untuk mengganti presiden, padahal calon presiden sudah ada. Tentu kejadian diatas telah menciderai aturan yang dibuat oleh negara, yakni pemilihan umum wajib menjamin tersalurkannya suara rakyat secara langsung, umum, bebas, rahasia, jujur dan adil. ${ }^{14}$ Makna dari sebuah demokrasi yang ideal adalah kebebasan berpendapat dengan menjunjung tinggi kemanusian. Malik Haramain dan Nurhuda mengemukakan beberapa standar yang harus menjadi acuan untuk mewujudkan pemilihan umum yang benar- benar demokratis termasuk pilpres sebagai bagian pemilu, yaitu' ${ }^{15}$ :

a. Pelaksanaan pemilu harus melibatkan semua warga negara tanpa diskriminasi sedikitpun, sehingga rakyat

\footnotetext{
kepada pihak berwajib, yakni Polda Metro Jaya dan Komnas Perempuan. https://www.idntimes.com/news/indonesia/margith-juita-damanik/hampir-semingguberlalu-laporan-korban diakses pada 19 September 2018

${ }_{13}$ Berita diperoleh dijejaring Facebook milik pribadi, kebanyakan menggunakan meme atau gambar serta video yang di manipulasi untuk saling menjatuhkan, diakses pada tanggal 23 Agustus 2018

${ }^{14}$ Konsideran Undang-undang Nomor 7 Tahun 2017 Tentang Pemilihan Umum huruf c.

15Ibid., 611.
} 
benar-benar mempunyai kepercayaan bahwa dirinya adalah perwujudan dari kedaulatan rakyat.

b. Pemilu dilaksanakan dengan perangkat peraturan yang mendukung atas kebebasan dan kejujuran, sehingga dengan adanya undang-undang yang lebih memberi kesempatan kebebasan pada warga negara, peluang ke arah pemilu yang demokratis dapat tercapai.

c. Pelaksanaan pemilu betul-betul dimaksudkan untuk memilih wakil-wakil rakyat yang berkualtas, memiliki integritas moral dan yang paling penting wakil-wakil tersebut betul betul mencerminkan kehendak rakyat.

Jelas di dalamnya ada sikap yang saling menghormati meskipun berbeda pilihan. Tidak memaksakan kehendak dengan cara-cara yang tidak dibenarkan oleh moral yang dijarkan di agamanya masing-masing. Mengantisipasi adanya percampuran agama dan kepentingan golongan politik yang berbeda. Ketika Bung Karno mengatakan bahwa beliau takut dengan generasi setelahnya yang akan berperang dengan bangsanya sendiri karena masa penjajahan sudah selesai. Hari ini masyarakat Indonesia sedang mengalami itu. Generasi ini harus membangun lagi karakter yang pernah kita terima dengaan menghargai semua perbedaan untuk menciptakan Pilpres yang demokratis dan berkeadilan. 


\section{Pembahasan}

\section{Moralitas Merupakan Manifestasi Dari Ajaran Agama}

Nilai atau "Value" termasuk bidang kajian filsafat. Filsafat nilai (Axiology, theory of value) sering juga diartikan sebagai ilmu tentang nilai-nilai. ${ }^{16}$ Istilah nilai di dalam bidang filsafat dipakai untuk menunjuk kata benda abstrak yang artinya "keberhargaan" atau "kebaikan" dan kata kerja yang artinya suatu tindakan kejiwaan tertentu dalam meniali atau melakukan penilaian. Di dalam Dictionary of Sociology and Related Sciences dikemukakan bahwa nilai adalah kemampuan yang dipercayai yang ada pada suatu benda untuk memuaskan manusia. Jadi nilai itu pada hakikatnya adalah sifat atau kualitas yang melekat pada suatu objek, tetapi bukan objek itu sendiri.

Nilai itu adalah suatu kenyataan yang tersembunyi dibalik kenyataan-kenyataan lainnya yang memiliki kemanfaatan bagi kehidupan manusia, baik lahir maupun batin. Agar nilai tersebut menjadi berguna dalam menuntun sikap dan tingkah laku manusia, maka perlu lebih dikonkritkan dan diformulasikan menjadi lebih objektif sehingga memudahkan untuk menjabarkannya dalam tingkah laku secara konkrit, inilah yang disebut sebagai norma. Nilai dan norma seantiasa berkaitan dengan moral dan etika. Istilah moral mengandung integritas dan martabat pribadi manusia.

\footnotetext{
${ }^{16}$ Kaelan,Pendidikan Pancasila, (Sleman : Paradigma, 2010), 87.
} 
Makna moral yang terkandung dalam kepribadian seseorang itu tercermin dari sikap dan tingkah lakunya dan norma sebagai penuntun sikap dan tingkah laku manusia itu sendiri. ${ }^{17}$

Agama atau religion adalah kepercayaan kepada Tuhan dengan ajaran kebaktian dan kewajiban-kewajiban yang bertalian dengan kepercayaan. Berbeda dengan keyakinan yang merupakan kepercayaan dan sebagainya yang sungguh-sungguh yang berwujud konsep-konsep yang menjadi keyakinan para penganutnya. Pasal 29 Ayat (2) UUD NRI 1945 menyebutkan bahwa negara menjamin kemerdekaan tiap-tiap penduduk untuk memeluk agamanya masing-masing dan untuk beribadat menurut agamanya dan kepercayaannya itu. ${ }^{18}$ Agama dalam etimologi tidak melulu dirujukkan pada eksistensi Tuhan, malah ada keselarasan antara etimologi dengan pengertian agama di masa Majapahit. Agama sebagai suatu kepercayaan kemudian beralih pada kepercayaan kepada tuhan, mengacu pada sila pertama pancasila Ketuhanan yang Maha Esa sehingg makna agama yang merujuk pada kepercayaan dalam Pasal 29 UUD NRI1945 juga harus dirujuk konsepsi Tuhan. Semua agama menganjurkan umatnya untuk tampil baik di dalam kehidupan sosial kemasyarakatan, termasuk bersikap baik

\footnotetext{
${ }^{17}$ Ibid, 93.

${ }^{18}$ Ilham Yuli Isdianto, Rekonstruksi Hukum Ketatanegaraan Indonesia, (Yogyakarta : UII Press, 2016), 46.
} 
kepada kalangan penganut agama-agama lain. Ini adalah teologi keagamaan secara umum. Teologi ini sekaligus perlu dijadikan basis perilaku menuju kesalehan sosial. Agama dan umat beragama harus dibebaskan dari perseteruan dan konflik sosial di masyarakat. ${ }^{19}$

Moral atau akhlak sebagaimana telah dimaksudkan di atas, berusaha mencari kebaikan sesuai dengan nilai-nilai luhur agama, adat istiadat, atau bahkan lahir dari hati yang suci dan nurani yang jujur. Hal ini menimbulkan etika yang menjadikan seorang moralis (budiman) karena dapat mebedakan antara yang baik dan yang buruk. ${ }^{20}$ Menyoal moralitas bersumber pada agama, tentu tidak terpisahkan dengan persoalan politik bangsa, yaitu agama dilestarikan atau sebaliknya.

Mengenai hal tersebut Al-Ghazalii ${ }^{21}$ sejalan dengan para filusuf Yunani yang mengatakan bahwa moral dan politik adalah dua saudara kembar yang tidak boleh terpisahkan. Moral sangat dibutuhkan oleh masyarakat untuk menentukan nilai baik, buruk, benar dan salah sari suatu tindakan dan keinginan seseorang dalam masyarakat. Sedangkan politik dibutuhkan untuk mengatur masyarakat sesuai dengan aturan-aturan moral yang diterima dan disepakati oleh

\footnotetext{
19Syamsul Bakri, “Agama, Persoalan Sosial, Dan Krisis Moral," Jurnal Dakwah STAIN Purwokerto 3, no. 1 (2009), 3.

${ }^{20}$ Inu Kencana Syafiie, Etika Pemerintahan, (Jakarta : Rineka Cipta, 2011), hlm. 3

${ }^{21}$ Abuddin Nata, dkk., Problematika Politik Islam Di Indonesia (Jakarta: PT Grasindo, 2002), 77 .
} 
masyarakat. Agama dan masyarakat merupakan bagian dari sistem sosial (fondasi dasar) dalam hubungan antara agama dan persaudaraan lintas agama. Hal itu dikarenakan manusia itu bersaudara, walaupun berbeda dalam menganut agama. Persaudaraan sebagai anak Adam muncul sebagai persaudaraan kemanusiaan yang sama-sama merupakan makhluk Tuhan. Sebagai bagian dari sistem sosial, Islam merupakan kekuatan sekaligus potensi besar dalam upaya membangun bangsa. Al-Quran menawarkan sebuah perspektif moderen yang khas tentang peran islam sebagai kekuatan yang toleran dan saling menghargai dalam dunia yang multi etnis dan multi komunitas :

"Bagi tiap-tiap umat (bangsa) di antara kamu, kami telah jadikan peraturan dan jalan yang terang. Dan kalau Allah menghendaki, niscaya kamu dijadikannya suatu umat (bangsa) saja, tetapi Allah hendak menguji kamu tentang apa yang telah diberikan-Nya kepada kamu, maka berlomba-lomba lah kamu berbuat kebajikan". ${ }^{22}$

Pemaparan di atas merupakan berbagai macam petunjuk untuk mengetahui nilai moral dari manifestasi ajaran agamayang dapat diperoleh adalah sebagai berikut :

1. Toleran dan saling menghormati antar sesama

2. Moralis (budiman) karena dapat mebedakan antara

\footnotetext{
${ }^{22}$ QS Al-Maidah ayat 48
} 
mana yang baik dan mana yang buruk

3. Jujur, netral dan tidak menerima suap

4. Adil

\section{Pemilihan Presiden Yang Demokratis Dan Berkeadilan}

Konsep demokrasi pada hakikatnya mempunyai keterkaitan yang erat dengan konsep pemilu. Berangkat dari pengertian demokrasi yang berarti pemerintahan dari rakyat, oleh rakyat, dan untuk rakyat, ${ }^{23}$ maka secara tidak langsung makna yang tersirat didalamnya bahwa kekuasaan negara berada ditangan rakyat dan segala tindakan negara ditentukan oleh rakyat. Untuk mewujudkan pengertian tersebut, pemilu dipercaya sebagai cara untuk mengangkat eksistensi rakyat sebagai pemegang kedaulatan tertinggi dalam negara.

IDEA (Institute For Democracy And Electoral Assistance) merumuskan sejumlah setandart yang bisa menjadikan tolak ukur demokratis tidaknya suatu pemilu. Adapun sumber utama standart pemilu yang demokratis adalah berbagai deklarasi dan konvensi internasional maupun regional seperti DU-HAM 1948, perjanjian Internasional tentang Hak-hak sipil dan politik 1960, konvensi Eropa tahun 1950 untuk kebebasan HAM dan Kebebasan Asasi, dan Piagam

${ }^{23}$ Asep Sahid Dan Subhan Sofian, Pendidikan Kewarganegaraan, (Bandung, Fokus Media, 2012), 120 
Afrika 1981 tentang Hak Manusia dan Masyarakat. ${ }^{24}$ Butler, dkk., menyebutkan Kriteria lain yang lebih rasional tentang pemilu yang demokratis adalah sebagai berikut ${ }^{25}$ :

1. Semua orang dewasa memiliki hak suara

2. Pemilu secara teratur dalam batas waktu yang ditentukan

3. Semua kursi di legislatif adalah subjek yang dipilih dan dikompetisiakan

4. Tidak ada kelompok substansi ditolak untuk membentuk partai dan mengajukan kandidat

5. Bertindak adil, tidak ada pengecualian hukum, tanpa kekerasan, intimidasi kepada kandidat

6. Pilihan dilaikaukan dengan bebas, rahasia, dihitung dan dilaporkan secara jujur

7. Hasil pemilu disimpan di kantor dan sisanya disimpan sampai hasil pemilu diperoleh

Agar pemilu yang demokratis terlembagakan dan berkesinambungan, maka $^{26}$ :

1. Adanya pengadilan independen yang menginterpretasikan peraturan pemilu

2. Adanya lembaga administrasi yang jujur, kompeten, dan non partisipan

3. Adanya pembangunan sistem kepartaian yang cukup

\footnotetext{
${ }^{24} \mathrm{Ibid}, \mathrm{hlm} .306$

${ }^{25}$ Gagasan dikutip oleh Sigit Pamungkas, Perihal Pemilu, Yogyakarta : Labiratorium Jurusan Ilmu Pemerintahan Fisipol UGM tahun 2009, 12.

${ }^{26}$ Sirajuddin dan Winardi., Op. Cit, 307.
} 
terorganisir untuk meletakkan pemimpin dan kebijakan alternatif yang dipilih

4. Penerimaan komunitas politik terhadap aturan main tertentu dan struktur dan pembatasan dalam mencapai kekuasaan.

Selain terwujudnya pemilu yang demokratis dengan syarat dan ketentuan di atas, tujuan pemilu adalah untuk berkeadilan. Untuk mewujudkanya seluruh pelaku pemilu harus selalu mengedepankan keadilan. Teori-teori hukum alam mualai Socrates hingga Francois Geny tetap mempertahankan keadilan sebagai mahkota hukum. Teoriteori ini menyangkut hak dan kebebasan, peluang kekuasaan, pendapatan dan kemakmuran. ${ }^{27}$ Dalam Pasal 22E ayat 1 UUD NRI 1945 dinyatakan, pemilihan umum dilaksanakan secara langsung, umum, bebas, rahasia, jujur dan adil setiap lima tahun sekali. Sesuai ketentuan tersebut, "adil" merupakan salah satu asas penyelenggaraan pemilu. Oleh karena itu, asas tersebut haruslah menjiwai sistem pemilu yang terdiri dari hukum pemilu (electoral law) maupun proses penyelenggaraan pemilu (electoral process). Diadopsinya asas "adil” dalam norma konstitusi terkait pemilu menunjukkan bahwa perwujudan negara hukum yang demokratis sebagaimana diamanatkan dalam Pasal 1 UUD NRI 1945 harus

\footnotetext{
${ }^{27}$ Jazim Hamidi dan dani Hartono, Konsep Kepemimpinan Multi Kultural Nusantara (Prespektif Wahyu Mahkutha Rama), (Kota Malang : Nuswantara, 2015), 49
} 
dilakukan secara berkeadilan. Peralihan sekaligus pelaksaaan kedaulatan tertinggi negara yang berada di tangan rakyat tidak boleh dilakukan secara tidak fair.

Terkait hal tersebut, IDEA mencatat bahwa electoral justice adalah dalam kerangka itu, keadilan pemilu mencakup sarana dan mekanisme serta mengandung tiga elemen, yaitu pencegahan terhadap sengketa pemilu (prevention of electoral disputes), penyelesaian terhadap sengketa pemilu (resolution of electoral disputes), dan alternatif penyelesaian sengketa pemilu di luar mekanisme yang ada (alternative of electoral disputes). Penyelesaian terhadap sengketa pemilu dapat dibagi ke dalam dua hal, yaitu koreksi terhadap kecurangan melalui electoral challenges dan hukuman bagi mereka yang melakukan kecurangan baik secara administatif maupun pidana. ${ }^{28}$ Menurut Ramlan Surbakti mengemukakan tujuh kriteria yang harus dipenuhi untuk mewujudkan pemilu yang adil dan berintegritas. Tujuh kriteria tersebut adalah ${ }^{29}$ :

1. Kesetaraan antarwarga negara, baik dalam pemungutan dan penghitungan suara maupun dalam alokasi kursi DPR dan DPRD dan pembentukan daerah pemilihan;

2. Kepastian hukum yang dirumuskan berdasarkan asas pemilu demokratis

\footnotetext{
${ }^{28}$ Khairul Fahmi, 'Menelusuri Konsep Keadilan Pemilihan Umum Menurut UUD 1945 (2016) Jurnal Cita Hukum, 168.

${ }^{29}$ Ramlan Surbakti, 'Pemilu Berintegritas Dan Adil' Harian Kompas edisi 14

Februari 2014 dalam https://lautanopini.wordpress.com/2014/o2/14/pemiluberintegritas-dan-adil/. Diakses pada 14 September 2018
} 
3. Persaingan bebas dan adil antarkontestan pemilu

4. Partisipasi seluruh pemangku kepentingan dalam seluruh rangkaian penyelenggaraan tahap pemilu

5. Badan penyelenggara pemilu yang profesional, independen, dan imparsial

6. Integritas pemungutan, penghitungan, tabulasi, dan pelaporan suara pemilu

7. Penyelesaian sengketa pemilu yang adil dan tepat waktu.

Lahirnya keadilan tidak terlepas dari pada hukum yang mengatur segala tatanan masyarakat, salah satunya tatanan keadilan. Jhon Rawls dalam bukunya yang berjudul $A$ Theory of Justice atau teori keadilan menyebutkan bahwa keadilan adalah fairness. Fairness merupakan sebuah konsepsi keadilan yang mengkoparasikan antara konsep tradisional tentang kontrak sosial yakni cara memahami masyarakat.

Keadilan sebagai feairness dimulai dengan adanya kesepakatan dengan pilihan konsep keadilan yang diinginkan untuk mengatur sebuah perubahan. Setelah kesepakatan dilakukan maka memilih sebuah konstitusi atau undangundang untuk menegakkan hukum, kesemuanya menjadi prinsip keadilan yang disepakati atau kontrak sosial yang sebut dengan istilah feirness. Dari pemaparan ini, Jhon Rawls memandang perubahan dan pembangunan harus berdasarkan dengan perjanjian yang disepakati atau hokum sebagaimana 
yang ketahui bahwa hukum pembangunan memperhatikan masyarakat demi keadilan sosial.

Keadilan menurut pandangan Rawls perlu melibatkan keseluruhan komponen dalam masyarakat, hal ini dikarenakan prinsip: Pertama, semua orang memiliki hak-hak kebebasan dasar yang sama bagi semua warga negara meliputi kebebasan politik untuk memilih dan dipilih untuk jabatanjabatan publik, kebebasan berpendapat dan berkumpul, kebebasan berkeyakinan, kebebasan untuk mempunyai milik pribadi dan kebebasan dari penahanan secara sewenangwenang. Keadilan merupakan sesuatu gagasan yang berlaku umum tetapi pada akhirnya dapat dirasakan secara subyektif. ${ }^{30}$

Kedua, ketimpangan ekonomi dan sosial perlu diatur termasuk dalam melakukan pembangunan sehingga orang dapat mendapatkan keuntungan dan seluruh struktur dapat diduduki setiap orang demi pembangunan yang berkeadilan. Penerapannya perlu melibatkan seluruh komponen dan elemen masyarakat ${ }^{31}$. Teori keadilan sebagai fairness hanya bisa diterapkan dalam suatu masyarakat demokratis, yang masyarakat tersebut tunduk terhadap peraturan-peraturan dan hukum-hukum yang dibuat, diterima, dan diakui keberlakuannya oleh masyarakat. Artinya, keadilan hanya bisa diwujudkan dalam suatu tatanan masyarakat bukan secara

30Jhon Rawls, Teori Keadilan (Yogyakarta: Pustaka Pelajar, 2011), 72. 3'Ibid., 3 
individu.

Manifestasi Moral Dalam Mengawal Pemilihan Presiden 2019 Yang Demokratis Dan Berkeadilan

Manifestasi nilai moralitas dalam kehidupan berbangsa dan bernegara tidak ada artinya bila tidak dituangkan dalam aksi nyata mengawal pemilihan presiden 2019 sehingga perlu memanifestasikan nilai moralitas berlandaskan agama guna memperkokoh tali persaudaraan sebangsa dan setanah air untuk mewujudkan pemilihan presiden yang demokratis dan berkeadilan. Nilai-nilai yang bersumber pada agama adalah nilai-nilai yang lahir pada adat istiadat, nilai luhur agama dan dari kata hati yang suci dan murni yang jujur. Muara nilainilai yang diajarkan adalah :

1. Toleran dan saling menghormati antar sesama

2. Moralis (budiman) karena dapat mebedakan antara mana yang baik dan mana yang buruk

3. Jujur, netral dan tidak menerima suap

4. Adil

Dengan modal inilah tujuan untuk memanifestasikan nilai-nilai tersebut mengawal pemilihan presiden yang demokratis dan berkeadilan dapat terwujud. Manifestasi nilai moral dalam Sistem domokrasi adalah sangat menjunjung tinggi kadaulatan rakyat $^{32}$ dan dapat ngutarakan aspirasinya

32 Pasal 1 Ayat (2) UUD NRI 1945: Kedaulatan berada di tangan rakyat dan dilaksanakan menurut Undang-undang. 
secara bebas dan nyata dalam setiap pemilu diselenggarakan. Di sini permasalahan yang sering muncul yakni ketika mengutarakan aspirasi namun tidak pada tempat dan waktu yang telah disepakati yang semua itu di tunggangi oleh kepentingan-kepentingan yang dilakukan oleh sekelompok orang agar tujuannya dapat terwujud. Peristiwa demikian hanya terjadi lima tahuan saja, namun keberadaannya dapat memecah belah elemen masyarakat.

Sebenarnya bila dilihat dengan konteks sistem, menurut Lawrance M. Friedman ${ }^{33}$ terdpat tiga komponen, yaitu hukum itu sendiri, pembuat hukum dan yang terkahir adalah budaya. Secara hukum dan pembuatan aturan tentang pemilu sudah menerapkan sistem yang benar-benar demokratis dan adil. Seperti yang diungkapkan oleh Ramlan Subakti34 sebagai berikut:

1. Kesetaraan antarwarga negara, baik dalam pemungutan dan penghitungan suara maupun dalam alokasi kursi DPR dan DPRD dan pembentukan daerah pemilihan

2. Kepastian hukum yang dirumuskan berdasarkan asas pemilu demokratis

3. Persaingan bebas dan adil antar kontestan pemilu

4. Partisipasi seluruh pemangku kepentingan dalam

\footnotetext{
33Juhaya S. Praja, Teori Hukum Dan Aplikasinya (Bandung: CV Pustaka Setia, 2014), 54 .

34Ramlan Subakti, Pemilu Berintegritas dan Adil, dikutip di Harian Kompas edisi 14 pada februari 2014, dalam https://lautanopini.wordpress.com/2014/o2/14/pemiluberintegritas-dan-adil/. Diakses pada 14 September 2018
} 
seluruh rangkaian penyelenggaraan tahap pemilu

5. Badan penyelenggara pemilu yang professional, independen, dan imparsial

6. Integritas pemungutan, penghitungan, tabulasi, dan pelaporan suara pemilu

7. Penyelesaian sengketa pemilu yang adil dan tepat waku.

Komponen ketiga inilah yang menjadi permasalahan ketika penyelenggaraan pemilu dilakukan, yakni sosial budaya. Mengingat perhelatan pemilu tahun 2014 silam masyarakat seakan terbelah menjadi dua golongan. Kegaduhan-kegaduhan timbul karena masyarakatnya bukan aturan hukumnya dan kejadian itu terjadi diwaktu dan tempat yang belum ditentukan oleh penyelenggara pemilu yakni Komisi Pemilihan Umum.

Secara demokratis sudah tercermin dalam masyrakat Indoensia, selanjutnya adalah permaslahan pada kontek berkeadilan. Di sini pentingnya memanifestasikan nilai moral bersumber pada agama. Menurut John Rawls, keadilan tidak dapat ditentukan dalam tatanan secara individu melainkan secara masyarakat. ${ }^{35}$ Dengan memiliki sifat moralis, toleran, dan jujur dalam perhelatan pemilu 2019 maka keadilan terwujud dengan cara memanifestasikannya dalam pemilu yang akan datang seperti :

1. Tidak membabibuta pada salah satu calon 
2. Dapat membedakan mana yang salah dan mana yang benar, ini digunakan untuk bijak bermedsos, menerima berita yang sebenarnya dan tidak menyebarkan beritaberita yang tidak sesuai

3. Toleran saling menghargai dan menghormati antar sesama. Meskipun sudah terpetakan kepada siapa pilihan diutarakan, harus menghormatinya jangan sampai kita memaksakan kehendak orang lain.

4. Jujur. Komponen ini sebenarnya menjadi penentu kedilan dapat terwujud, seperti tidak menerima suap untuk memilih salah satu calon dan tidak memaksakan pilihan seseorang dengan uang atau pun bentuk lainya, Fair Play.

Perwujudan nilai moralitas bersumber pada agama memang sangat penting sekali dan harus tercermin serta melekat dalam setiap diri manusia. Serta mengimplikasikannya pada pemilihan presiden 2019 agar dapat mewujudkan pemilihan presiden yang demokratis dan berkeadilan, yaitu: toleran, saling menghargai pendapat orang lain, jujur, mampu membedakan yang benar dan yang salah dan yang terakhir adalah adil baik tindakan maupun fikiran.

\section{Kesimpulan}

Setelah menguraikan definisi-definisi dan mengkaji nilai moralitas agama bersumber dari agama dan 
memformulasikan untuk mewujudkan pemilihan presiden yang demokratis dan berkeadilan, berikut diungkapkan catatan akhir sebagai simpulan, sebagai berikut: pertama, pilpres yang telah menjadi komitmen konstitusional bangsa dan negara Indonesia merupakan sarana pelaksanaan kedaulatan rakyat, yang tampak melalui keikusertaan rakyat (pemilih) dalam menentukan pemimpin nasional (presiden dan wakil presiden).

Kedua, penyelenggaraan pemilihan presiden 2019 menyisakan problematika, berkenaan dengan (a) terpecah belahnya masyarakat menjadi dua golongan menyesuaikan kepada pilihannya; (b) memilih secara terang-terangan kepada salah satu calon sebelum pemilu dilaksanakan; (c) pilihan secara membabibuta kepada salah satu calon; (d) tidak terwujudnya rasa toleran saling menghormati kepada seseorang atau kelompok yang berbeda pendapat. Ketiga, nilai moral yang bersumber pada agama adalah nilai-nilai yang lahir dari nilai luhur suatu agama, adat istiadat, hati dan fikiran yang suci, yaitu toleran, saling menghargai pendapat orang lain, jujur, mampu membedakan yang benar dan yang salah dan yang terakhir adalah adil baik tindakan maupun fikiran. Dalam rangka mewujudkan nilai moralitas mengawal pemilihan presiden 2019 yang demokratis dan berkeadilan, beberapa hal berikut patut menjadi perhatian bersama: a. Pembentukan norma pemilu yang berkualitas dan responsif, 
penyelenggara yang berkualitas, mandiri, tidak memihak dan berintegritas, pemilih yang rasional, cerdas dan bermoral, peran pemerintah yang lebih diintensifkan. b. Saling menghargai dan menghormati pendapat antar sesama tidak saling menjatuhkan, rasional, mendidik, bijak bermedsos, Hablumminallah dan Hablummniannas, yang terakhir adalah tidak menerima suap atau jujur.

\section{Daftar Pustaka}

Tricahyo, Ibnu., 20 o9, Reformasi Pemilu Menuju Pemisahan

Pemilu Nasional dan Lokal, In Trans Publishing, Malang.

Kaelan, 2010, Pendidikan Pancasila, Paradigma, Sleman.

Kencana Syafiie, Inu, 2011, Etika Pemerintahan, Rineka Cipta, Jakarta.

Muhadam Labolo, Teguh Ilham., 2015, Partai Politik dan

Sistem Pemilihan Umum DI Indonesia, Rajawali Perss, Jakarta.

Asep Sahid Dan Subhan Sofian, 2012, Pendidikan Kewarganegaraan, Fokus Media, Bandung.

Sirajuddin dan Winardi., 2016, Dasar-dasar Hukum Tata

Negara Indonesia, Malang, Setara Perss, Malang.

Sigit Pamungkas, 2009. Perihal Pemilu, Yogyakarta :

Labiratorium Jurusan Ilmu Pemerintahan Fisipol UGM

Jazim Hamidi dan dani Hartono,2015, Konsep Kepemimpinan

Multi Kultural Nusantara (Prespektif Wahyu Mahkutha 
Rama), Nuswantara, Kota Malang.

Dr. H. Abuddin Nata, dkk. Problematika Politik Islam Di Indonesia. Jakarta: PT Grasindo, 2002.

Jhon Rawls. Teori Keadilan. Yogyakarta: Pustaka Pelajar, 2011.

Juhaya S. Praja. Teori Hukum Dan Aplikasinya. Bandung: CV Pustaka Setia, 2014.

Rahadian, Lalu. "Catatan PolMark: Perpecahan Masyarakat Karena Pemilu Nyata.” tirto.id, n.d.

Rauta, Umbu. "Menggagas Pemilihan Presiden Yang Demokratis Dan Aspiratif." Jurnal Konstitusi 11, no. 3 (2014).

Bakri, Syamsul. “Agama, Persoalan Sosial, Dan Krisis Moral.” Jurnal Dakwah STAIN Purwokerto 3, no. 1 (2009).

Khairul Fahmi, 2016, Menelusuri Konsep Keadilan Pemilihan Umum Menurut UUD 1945, Jurnal Cita Hukum.

Yuli Isdianto, Ilham, 2016, Rekonstruksi Hukum Ketatanegaraan Indonesia, UII Press, Yogyakarta. 